\title{
An In-silico and In-vitro Comparative Study of Compounds from Phoenix sylvestris Roxb. For Alpha- Amylase Enzyme Inhibition Involved in Diabetes Mellitus
}

\author{
Dinesh C. Sharma ${ }^{1, * \mathbb{D}}$, Parvindra Kumar ${ }^{1}{ }^{\mathbb{D}}$, Imran Hussain ${ }^{1} \mathbb{D}$, Satish K. Sharma ${ }^{2 \mathbb{C}}$ \\ 1 School of Life and Allied Health Sciences, The Glocal University, Saharanpur, India \\ 2 School of Pharmacy, The Glocal University, Saharanpur, India \\ * Correspondence: : ddcsharma@gmail.com, dinesh.chandra@theglocaluniversity.in;
}

Received: 28.12.2020; Revised: 27.01.2021; Accepted: 31.01.2021; Published: 9.02.2021

\begin{abstract}
Identification of potential phytocompound from Phoenix sylvestris RoxB. For anti-diabetic potential and its validation through computational methods. Partially purified fraction evaluated for Alpha-amylase enzyme inhibition and GC-MS identified fraction validated compounds for potential anti-diabetic activity by Auto docking method. The phytocompounds investigation revealed maximum abundance of total phenol ( $31.55 \pm 0.55 \mu \mathrm{g} / \mathrm{mg}$ equivalent to Gallic acid) and flavonoid (52.90 \pm 0.08 $\mu \mathrm{g} / \mathrm{mg}$ equivalent to quercetin) content in ethyl acetate extract. Ethyl acetate extract interestingly showed maximum alpha-amylase inhibition $(71.15 \%$, IC50- $98.50 \pm 0.10 \mu \mathrm{g} / \mathrm{ml})$, which was a mixed type of inhibition as compared to acarbose $(78.64 \%$, IC50- $88.61 \pm 0.50 \mu \mathrm{g} / \mathrm{ml})$, which showed a competitive type of inhibition analyzed by Line weaver-Burk double reciprocal plot versus 1/v and 1/s. The docking study illustrated that Lupenyl acetate compound was the most active compound that showed maximum binding free energy $(-7.16 \mathrm{Kcal} / \mathrm{mol})$ and interacted with the Val64, Asn88, Gly90, Asn87, Arg87, Arg10, Gly9, Gln7, Gln5, Thr5, Trp221, Phe222, Asn5, Pro223, Ser3, Ser226, Lys227 and Gly225 amino acid residues which inhibited the alpha-amylase more efficiently than acarbose (binding energy $-4.71 \mathrm{Kcal} / \mathrm{mol}$ ). The present study concluded that the components of ethyl acetate extract had Alpha enzyme inhibition with reducing potential, and it may be due to the synergistic effect. The study suggested ethyl acetate extract as a natural promising therapeutic compound for the treatment of diabetes.
\end{abstract}

Keywords: alpha amylase; acarbose; gas chromatography-mass spectrometry; auto dock.

(C) 2021 by the authors. This article is an open-access article distributed under the terms and conditions of the Creative Commons Attribution (CC BY) license (https://creativecommons.org/licenses/by/4.0/).

\section{Introduction}

Around the globe, there are approx 300 million people being affected by diabetes mellitus. Diabetes is defined by decreased blood glucose homeostasis, including the overture to high blood glucose levels with some lipid parameters modification (International Diabetes Federation, 2013). In the intervening time, a prolonged increase of blood glucose may cause the overproduction of ROS (Reactive Oxygen Species) accompanied by oxidative stress. This causes various diseases, including cardiovascular diseases, diabetes, degenerative diseases, cancer, inflammation, ischemia, and anemia [1-3]. Various synthetic drugs have been developed in the last decades, which help to control oxidative stress. However, these drugs have numerous side effects, toxicity, high cost, and less accessibility. In contrast, herbal medicines gain popularity as they have no side effects, minimal toxicity, easily available, less expensive, and are approximately found in all plants [4]. Plants are a very rich source of 
antioxidant compounds, which essentially neutrilizing the free radicals and help in the development of an immune system, and hence, these are very effective in diseases that are caused due to oxidative stress [5-6]. Previous studies have shown that antioxidant property to the plants is provided by flavonoids and phenolics components [7-10] that have tremendous anti-diabetic potential [11-13]. Phenol and flavonoids have been well studied for their antimicrobial, anti-diabetic, anti-cancer, and anti-inflammatory properties, and excellent effects have been observed in in-vivo experiments [14].

Arecaceae is a family of dominant perennial trees commonly called palm trees, which are distributed in tropical, subtropical, and warm climates [15-16]. The Indian date palm, Phoenix sylvestris is an evergreen plant that grows well in all types of environmental conditions and habitat from rain forest to deserts [17]. Date palms have been reported as a source of various phytocompounds used since prehistoric times for good health and treatment of various ailments. Plants synthesize various types of phytocompounds, which are grouped as primary and secondary metabolites. Primary metabolites include several sugars and fat components, which are essential for plants' growth and development. However, Secondary metabolites are produced in plants as a result of their protective and defensive activities. Mostly biologically active components from plant sources are secondary metabolites. These secondary metabolites included phenolics, flavonoids, trepans, alkaloids, saponins, and sterols, which were practiced to treat various disorders. Extraction of phytocompounds from any source by solvents depended upon the polarity characteristics. The group of extracting compounds is also an important part of any pharmaceutical pieces of evidence. Therefore, in the present study, attempts have been made to investigate the phytochemicals of Phoenix sylvestris. Alphaamylase is a hydrolyzing enzyme involved in the digestion of carbohydrates in glucose, which absorbed and increased the blood glucose level. The alpha-amylase inhibiting formulation can be playing an important role in the prevention of diabetic-like conditions.

\section{Materials and Methods}

\subsection{Collection of plant and authentication.}

The leaf Samples of Phoenix sylvestris were collected from the Kukrail forest area Lucknow, and the specimens were identified and authenticated as Phoenix sylvestris RoxB.In BSIP (Birbal Sahni Institute of Palaeobotany), Lucknow, India. The dried fine powder of leaf was used for the extraction from different individual solvents [18]. The solvent was removed, filtered, and dried at room temperature, and residues were scratched out and stored at $-20^{\circ} \mathrm{C}$ for further use. The percentage yield of different extracts was calculated by using the formula:

$$
\% \text { Yield }=\frac{\text { Weight of crude extract }}{\text { Weight of raw material }} X 100
$$

\subsection{Chemical and reagents.}

All the chemicals and reagents were purchased from authenticated suppliers. Solvents like ethyl acetate, chloroform, acetone, butanol, cyclohexane, propanol, ethanol, and benzene were obtained from Merck, India, for extraction. Chemicals used for alpha-amylase assay: dinitrosalicylic acid (DNS), gallic acid, sodium carbonate $\left(\mathrm{Na}_{2} \mathrm{CO}_{3}\right)$, aluminium chloride, quercetin, potassium acetate reagents were purchased from HiMedia Laboratories, Mumbai, 
India, acarbose (GLUCOBAY ${ }^{\mathrm{TM}}$ ), and a standard drug was purchased from the local market. All other chemicals used were of analytical grade.

\subsection{Determination of total phenol content (TPC).}

Total phenolic contents in leaf extracts of Phoenix sylvestris were determined by the Folin-Ciocalteu method given by McDonald and co-workers [14]. Leaf extract of all solvents was dissolved in methanol $(1 \mathrm{mg} / \mathrm{ml}$ concentration) and filtered. $5 \mathrm{ml}$ of the mixture contained $0.5 \mathrm{ml}$ of extract or reference (Gallic acid), $2 \mathrm{ml}$ (1N aqueous) $\mathrm{Na}_{2} \mathrm{CO}_{3}$, and $2.5 \mathrm{ml}$ of $(2 \mathrm{~N}$ ) Folin-Ciocalteu reagent (Sigma-Aldrich, Germany). The test mixture was incubated at room temperature for 15 minutes. The absorbance at $765 \mathrm{~nm}$ was measured using a spectrophotometer (Eppendorf). The standard curve was prepared using 12.5 to $500 \mu \mathrm{g} / \mathrm{ml}$ solution of Gallic acid in methanol. The blank contained $500 \mu \mathrm{l}$ of double-distilled water, $\mathrm{Na}_{2} \mathrm{CO}_{3}$, and the Folin-Ciocalteu reagent. Total phenol values are expressed in terms of Gallic acid equivalent $(\mu \mathrm{g} / \mathrm{mg}$ of extract).

\subsection{Determination of total flavonoid content (TFC).}

The quantitative estimation was performed spectrophotometrically by the aluminum chloride method based on complex flavonoid-aluminum formation [18]. Phoenix sylvestris of all solvents was dissolved in methanol $(1 \mathrm{mg} / \mathrm{ml}$ concentration) and filtered. Aliquots of $0.5 \mathrm{ml}$ of each sample were mixed with $1.5 \mathrm{ml}$ of methanol, $0.1 \mathrm{ml}$ of $10 \%$ Aluminium Chloride, 0.1 $\mathrm{ml}$ of (1M) Potassium acetate, and $2.8 \mathrm{ml}$ of distilled water. It was incubated for 30 minutes at room temperature. The absorbance of the test mixture was observed at $415 \mathrm{~nm}$. The calibration curve was prepared by Quercetin standard solutions at various concentrations 12.5 to $500 \mu \mathrm{g} / \mathrm{ml}$ in methanol. Total flavonoid values are expressed in terms of Quercetin equivalent $(\mu \mathrm{g} / \mathrm{mg}$ of extract).

\subsection{Alpha-amylase inhibition assay.}

The in-vitro alpha-amylase inhibition assay of different solvent leaf extracts of Phoenix sylvestris was performed following the standard protocol with some modification [19]. Alphaamylase was dissolved in $20 \mathrm{mM}$ ice-cold phosphate buffer with $\mathrm{pH} 6.7$, containing $6.7 \mathrm{mM}$ sodium chloride to maintain a $0.15 \mathrm{unit} / \mathrm{ml}$ concentration. Each test tube containing $250 \mu \mathrm{l}$ of the enzyme was mixed with $100 \mu \mathrm{l}$ of all extracts except the blank. The mixture was vortexes and incubated in a water bath for 20 minutes at $37^{\circ} \mathrm{C}$. After incubation, $250 \mu \mathrm{lof} 0.5 \% \mathrm{w} / \mathrm{v}$ starch in $20 \mathrm{mM}$ phosphate buffer ( $\mathrm{pH}$ 6.7) was added into each tube to start the reaction, vortexed, and incubated for 15 minutes at $37^{\circ} \mathrm{C} .2 \mathrm{ml}$ of DNS (40 mM DNS, $1 \mathrm{M} \mathrm{K}-\mathrm{Na}$ tartrate, and $0.4 \mathrm{M}$ sodium hydroxide) was added vortexed and boiled for 10 minutes in a water bath at $100^{\circ} \mathrm{C}$. After that, the mixture was cooled down, and absorbance was observed at $540 \mathrm{~nm}$. Acarbose was used as standard. Inhibition was calculated by using the formula:

$$
\text { Percent inhibition }=100-\text { percent reaction }
$$

Where percent reaction $=($ mean product in sample $/$ mean product in control $) \times 100$.

Further, $\mathrm{IC}_{50}$ value represents the concentration of the extract exhibiting $50 \%$ inhibition of alpha-amylase.

\subsection{Determination of mode of inhibition.}


Determination of mode of inhibition of $\alpha$-amylase against the extract was determined by the standardized protocol of Mogale and co-workers [20]. In the analysis, two sets of 6 duplicate test tubes were set to analyze the enzyme activity in the presence and absence of an inhibitor (standard acarbose/extract). In the presence of inhibitor, $100 \mu \mathrm{l}$ of inhibitor (plant extract or acarbose, $1 \mathrm{mg} / \mathrm{ml}$ ) solution was added in each test tube except the blank; this was followed by the addition of $100 \mu \mathrm{l}$ of the porcine enzyme $\alpha$-amylase $(0.15 \mathrm{units} / \mathrm{ml})$. In another set of tubes, $100 \mu \mathrm{l}$ of $20 \mathrm{mM}$ phosphate buffer at $\mathrm{pH} 6.7$ and $6.7 \mathrm{mM}$ sodium chloride was added in each test tube, followed by $100 \mu \mathrm{l}$ of the enzyme solution. All the test tubes were thoroughly mixed in a vortex mixer and incubated in a water bath at $37^{\circ} \mathrm{C}$ for 20 minutes. Serial dilutions of the substrate solution were added in all the test tubes with concentrations ranging between $2.5 \mu \mathrm{g} / \mathrm{ml}$ and $0.156 \mu \mathrm{g} / \mathrm{ml}$ and incubated for 15 minutes at $37^{\circ} \mathrm{C}$. $2 \mathrm{ml}$ of colored reagent DNS was added to each tube and then boiled for 10 minutes. Absorbance was recorded at $540 \mathrm{~nm}$. Double reciprocal curve $(1 /[\mathrm{V}]$ vs. $1 /[S])$ with inhibitor and without inhibitor was plotted to analyze the effect of the extract and standard acarbose on $V \max$ and $\mathrm{Km}$ of the enzyme, where $V$ and $S$ are, respectively, the velocity of the reaction and substrate concentration.

\subsection{Gas chromatography-mass spectrometry analysis.}

The potential extract was homogenized in the appropriate solvent, and GC-MS analysis of the sample was carried out by the following process in the GC-MS machine (model GCMS-QP-2010 plus, Shimadzu Make). The test sample (1 $\mu \mathrm{l})$ was used as an injector in RTX-5 column of GC-MS. The Carrier gas helium was used at a regular flow of $1.2 \mathrm{ml}$ per minute. The temperature was maintained in the range of $100^{\circ} \mathrm{C}$ to $200^{\circ} \mathrm{C}$. The temperature for the ion source and injector were $250^{\circ} \mathrm{C}$ and $270^{\circ} \mathrm{C}$, respectively. Further, mass spectra investigation carried out at fragments ranges from 40 to 950 Dalton. The phytoconstituents were finally confirmed by using the reference compound data present in the Wiley and NIST (National Institute Standard and Technology) mass spectral database.

\subsection{Docking analysis.}

Molecular docking of major GC-MS identified compounds and standard acarbose with alpha-amylase enzyme was carried out using Auto Dock Tools [21] to find the preferred binding conformations of the ligands in the receptor. The binding conformation analysis of the protein-ligand complex was performed using a scoring function based on the free energy of binding [22]. The 3D structure of porcine alpha-amylase (PDB ID: 1DHK) for Auto-docking study was obtained from Research Collaboratory for Structural Bioinformatics (RCSB), and 3D structure of each GC-MS identified compound was retrieved from Pubchem database, which was further converted to compatible pdb file with the help of Discovery Studio 2.5 visualize. Among the stochastic search algorithms offered by Auto Dock suite, the Lamarckian Genetic Algorithm (LGA), which combines global search (Genetic Algorithm alone) to local search Solis and Wets [23] algorithm was chosen. The grid parameter file of the receptor was generated using Auto Grid. The number of grid points in x, y, and z-axes was $50 \times 50 \times 50^{\circ} \mathrm{A}$. The distance between the two connecting grid points was $0.603^{\circ}$ A. Auto Dock 1.5.6 and Lamarckian Genetic Algorithm (LGA) were used for docking calculations. Ten search attempts (GA run parameter) were performed for each ligand. The maximum number of energy evaluations before the termination of LGA run was 2,500,000, and the maximum number of 
generations was 27,000, and other parameters were set to the software's default values. After complete Auto Dock execution, ten conformations of the ligand in a complex with the receptor were obtained, which were finally ranked based on interaction energies and inhibition constant (Ki). The enzyme-ligand interaction analysis and illustration were performed by discovery studio visualize.

\section{Results and Discussion}

\subsection{Phytochemical analysis.}

All the extracts of $P$. sylvestris leaf were extracted using various types of solvents in which the maximum percent yield (5.22\%) was observed in ethyl acetate solvent extract. All the samples were analyzed to evaluate potential extract having a maximum amount of total phenolic and flavonoid contents. Among all the solvent extracts, ethyl acetate extract was identified to contain a higher amount of total phenolic $(31.55 \pm 0.55 \mu \mathrm{g} / \mathrm{mg}$ of extract equivalent Gallic acid) and total flavonoid $(52.90 \pm 0.08 \mu \mathrm{g} / \mathrm{mg}$ of extract equivalent to quercetin) contents followed by other extracts described in table 1 .

Table 1. Percent yield and quantitative phytochemical analysis.

\begin{tabular}{l|c|c|c} 
Extracts & Percent yield & $\begin{array}{c}\text { TPC } \\
\boldsymbol{\mu g} / \mathbf{m g} \text { of extract equivalent gallic } \\
\text { acid }\end{array}$ & $\begin{array}{c}\boldsymbol{\mu g} / \mathbf{m g} \text { of extract equivalent to } \\
\text { quercetin }\end{array}$ \\
\hline ethyl acetate & 5.22 & $31.55 \pm 0.55$ & $52.90 \pm 0.08$ \\
\hline butanol & 2.50 & $11.804 \pm 0.52$ & $20.65 \pm 0.30$ \\
\hline chloroform & 2.10 & $13.20 \pm 0.04$ & $20.235 \pm 0.5$ \\
\hline acetone & 2.30 & $10.75 \pm 0.35$ & $17.65 \pm 0.40$ \\
\hline ethanol & 4.20 & $22.60 \pm 0.4$ & $33.70 \pm 0.5$ \\
\hline cyclohexane & 3.90 & $17.30 \pm 0.07$ & $24.90 \pm 0.40$ \\
\hline 2-propanol & 3.50 & $15.65 \pm 0.5$ & $23.00 \pm 0.60$ \\
\hline benzene & 2.40 & $12.65 \pm 0.4$ & $21.75 \pm 0.5$
\end{tabular}

All experiments were performed in a triplicate manner and expressed as \pm S.D. values, $n=3$.

\subsection{Alpha-amylase assay.}

In-vitro anti-diabetic activity of the $P$. sylvestris leaf extracts was carried out by the inhibitory analysis of the alpha-amylase enzyme. Acarbose was used as a standard drug to compare the inhibitory effects. Among all extracts, ethyl acetate extract showed maximum inhibition (71.15\%) against alpha-amylase enzyme whereas, standard acarbose showed $78.64 \%$ inhibition at $500 \mu \mathrm{g} / \mathrm{ml}($ table 2). Also, the ethyl acetate extract showed a concentrationdependent increase in percent inhibition of alpha-amylase and showed lower IC $_{50}$ value $(98.50 \pm 0.10 \mu \mathrm{g} / \mathrm{mL})$ as compared to acarbose $(88.61 \pm 0.50 \mu \mathrm{g} / \mathrm{mL})$, which clearly showed the potential of extract for an anti-diabetic property (fig. 1).

\subsection{Determination of mode of inhibition.}

In-vitro results of alpha-amylase inhibition demonstrated the significant potential of ethyl acetate leaf extract of $P$. sylvestris comparable to the standard drug acarbose. The mode of inhibition of both was analyzed by Lineweaver-Burk double reciprocal plot between $1 /[v]$ and $1 /[S]$. Ethyl acetate extract showed a mixed type of enzyme inhibition, whereas acarbose competitively showed inhibition. Maximum velocity of the inhibition reaction was observed $V_{\max }=0.751$ and 0.510 for ethyl acetate extract (at $\mathrm{Km}=0.138$ ) and acarbose (at $K m=0.500$ ), respectively (fig. 2). Maximum velocity indicated the requirement of low substrate 
concentration for enzyme inhibition. As the substrate concentration increased, the reaction rate decreased, so inhibition of alpha-amylase directly depends on the substrate concentration.

Table 2. Alpha-amylase inhibition assay.

\begin{tabular}{l|c|c} 
Extracts & Percent Inhibition & IC $\mathbf{5 0}$ value $(\boldsymbol{\mu g} / \mathbf{m L})$ \\
\hline ethyl acetate & 71.15 & $98.50 \pm 0.10$ \\
\hline butanol & 58.90 & $298.55 \pm 0.5$ \\
\hline chloroform & 60.40 & $142.65 \pm 0.6$ \\
\hline acetone & 58.50 & $302.25 \pm 0.7$ \\
\hline ethanol & 63.80 & $124.9 \pm 0.3$ \\
\hline cyclohexane & 60.62 & $173.23 \pm 0.4$ \\
\hline 2-propanol & 59.00 & $290.66 \pm 0.8$ \\
\hline benzene & 50.40 & $405.52 \pm 0.72$ \\
\hline acarbose & 78.64 & $88.61 \pm 0.45$
\end{tabular}

Percent inhibition was calculated at a maximum concentration of $500 \mu \mathrm{g} / \mathrm{mL}$. All experiments were performed in a triplicate manner and expressed as \pm S.D. values, $n=3$

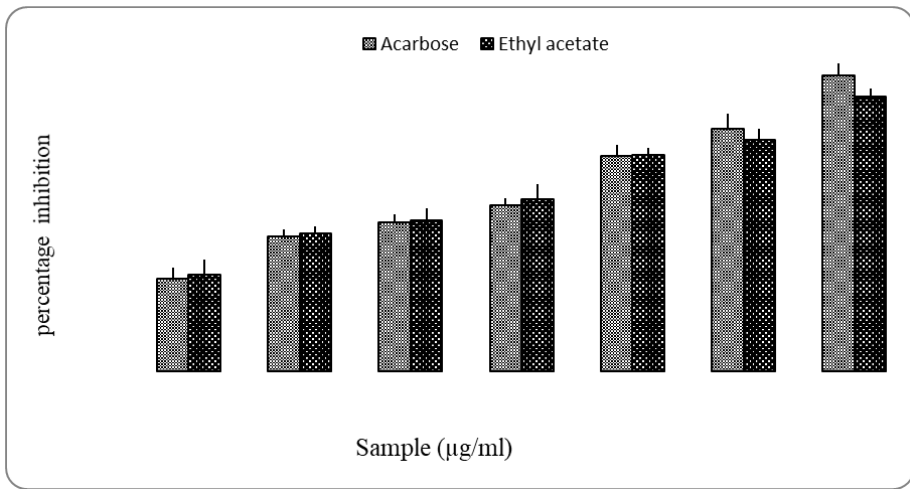

Figure 1. Concentration-dependent inhibition of alpha-amylase enzyme by ethyl acetate extract and standard compound acarbose. The results are expressed as mean \pm S.D., $n=3$.

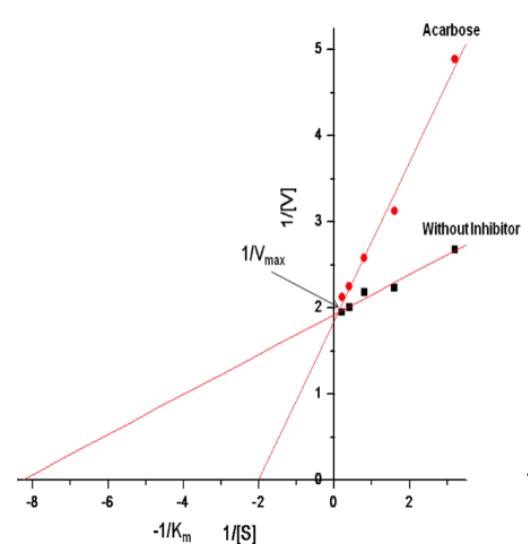

[A]

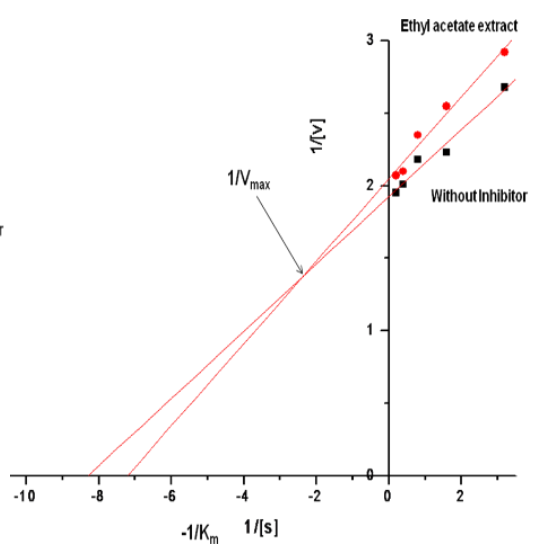

[B]

Figure 2. Lineweaver-Burk double reciprocal plot versus $1 / \mathrm{v}$ and $1 / \mathrm{s}$ against alpha-amylase of acarbose [A] and ethyl acetate extract [B].

\subsection{GC-MS analysis.}

The major identified compounds of the GC-MS analysis of ethyl acetate leaf extract $P$. sylvestris are shown in table 3. The spectrum shows peaks with percent area is shown in figure 3. According to their elution order, the eight major compounds identified were arranged with their Retention Time and Percent Area. The GC-MS result was identified for over 35 compounds like fatty acid flavonoid and terpenoid in nature. Out of them, all the eight compounds had a relatively maximum percent area. These major compounds were identified as hexadecanoic acid (17.28\%), 4H-pyran-4-one, 2-hydroxy-3 methyl (10.02\%), 9,12- 
octadecadienoic acid (9Z,12Z)-ethyl ester (8.32\%), tetradecanoic acid (8.18), lupenyl acetate (8.05\%), phthalic acid, mono-(2-ethylhexyl) ester (5.89\%), stigmast-5-en-3-ol (3.87\%), 9-12, octadecadienoic acid (2.11\%). These phytocompounds are well-known plant-derived antibacterial, antioxidant, and anti-inflammatory agents.

Table 3. Major compounds identified from ethyl acetate extract.

\begin{tabular}{|c|c|c|c|c|}
\hline R. Time & Percent area & Compound name & Compound nature & Activity $^{* *}$ \\
\hline 7.053 & 10.02 & $\begin{array}{l}\text { 4H-pyran-4-one, 2-hydroxy- } \\
\text { 3-methyl }\end{array}$ & Flavonoid & $\begin{array}{l}\text { Anti-inflammatory, Antifungal, } \\
\text { antioxidant }\end{array}$ \\
\hline 15.567 & 8.32 & $\begin{array}{l}\text { 9,12-octadecadienoic } \\
\text { (9Z,12Z)-methyl ester }\end{array}$ & Fatty acid ester & Bactericide, Fungicide \\
\hline 21.584 & 8.18 & $\begin{array}{l}\text { Tetradecanoic acid (Myristic } \\
\text { acid) }\end{array}$ & Fatty acid & $\begin{array}{lr}\text { Antioxidant, } & \\
\text { hypocholesterolemic } & \\
\text { nematicide, } & \text { pesticide, } \\
\text { antiandrogenic } & \text { flavor, } \\
\text { hemolytic, 5-Alpha } & \text { reductase } \\
\text { inhibitor } & \\
\end{array}$ \\
\hline 25.601 & 17.28 & $\begin{array}{l}\text { Hexadecanoic acid } \\
\text { (Palmitic acid) }\end{array}$ & Fatty acid & $\begin{array}{lr}\text { Antioxidant, } \\
\text { hypocholesterolemic } \\
\text { nematicide, } & \text { pesticide, } \\
\text { antiandrogenic } & \text { flavor, } \\
\text { hemolytic, 5-Alpha } & \text { reductase } \\
\text { inhibitor } & \\
\end{array}$ \\
\hline 28.715 & 2.11 & 9-12,Octadecadienoic acid & Fatty acid & $\begin{array}{lr}\text { Antioxidant, } & \text { antibacterial } \\
\text { activity, anti-inflammatory, } \\
\text { antiarthritic, antiasthma, } \\
\text { diuretic }\end{array}$ \\
\hline 35.446 & 5.89 & $\begin{array}{l}\text { Phthalic acid, mono-(2- } \\
\text { ethylhexyl) ester }\end{array}$ & Fatty acid ester & Antioxidant, Antimicrobial \\
\hline 45.776 & 3.87 & stigmast-5-en-3-ol & Terpenoid & Antioxidant, Anti-microbial \\
\hline 46.550 & 8.05 & Lupenyl acetate & Terpenoid & Antioxidant, Antimicrobial \\
\hline
\end{tabular}

(**activity was confirmed by Dr. Dukes medicinal plant compounds reference book.)

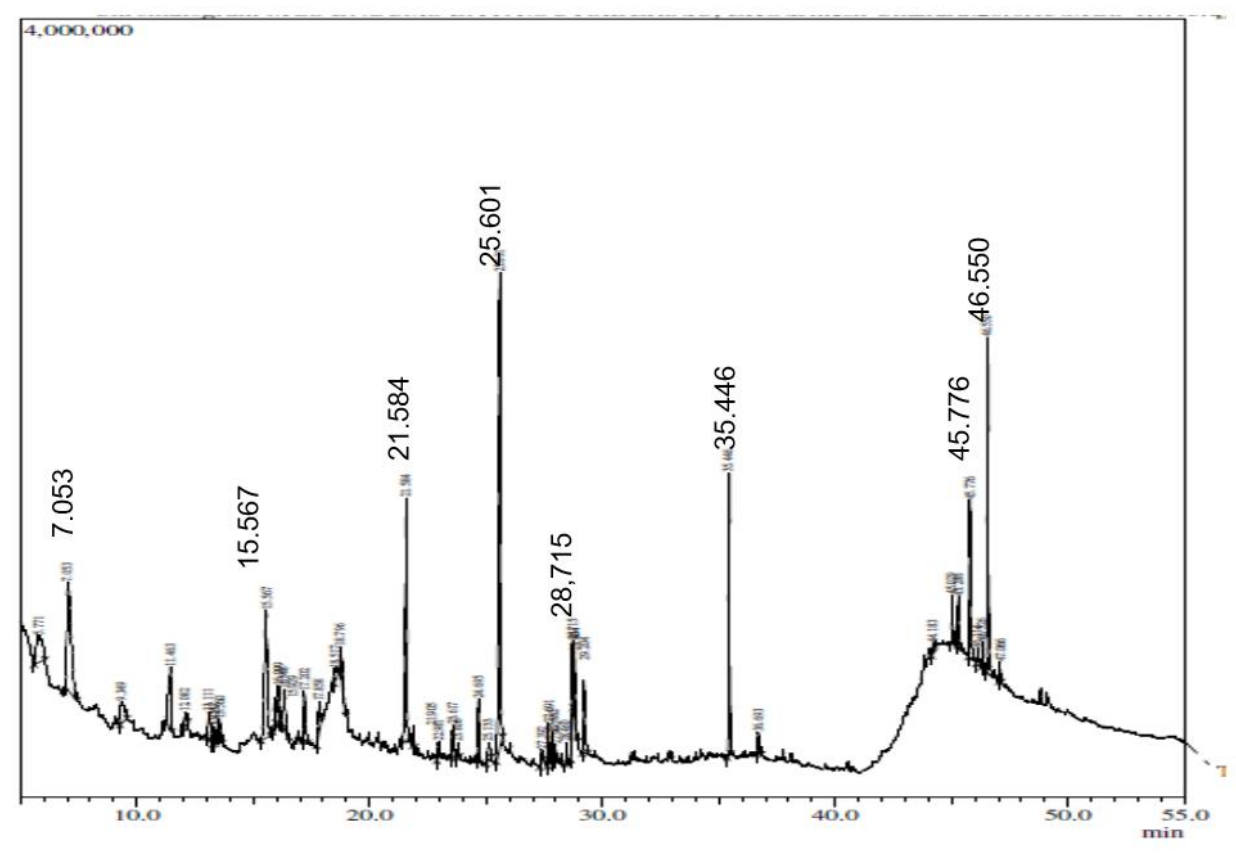

Figure 3. GC-MS graph of Ethyl acetate extract.

\subsection{Docking results.}

The in-vitro results showed ethyl acetate extract as a potential alpha-amylase inhibitor compared to standard acarbose. Furthermore, the in-silico docking study was carried out to assume high docking values, which will help predict the potential component of extract for 
alpha-amylase inhibition. All major GC-MS identified compounds' docking results demonstrated their strong binding with the enzyme, and the binding free energies range between -3.23 to $-7.16 \mathrm{Kcal} / \mathrm{mol}$ (Table 4 ). The docking study illustrated that the Lupenyl acetate compound was the most active compound, followed by stigmast-5-en-3-ol, Phthalic acid, mono-(2-ethylhexyl) ester, Tetradecanoic acid, 4H-pyran-4-one, 2-hydroxy-3-methyl 9,12-octadecadienoic acid (9Z,12Z)-methyl ester, Hexadecanoic acid, and 9,12octadecadienoic acid. Lupenyl acetate compound showed maximum binding free energy (-7.16 $\mathrm{Kcal} / \mathrm{mol}$ ) and interacted to the Val64, Asn88, Gly90, Asn87, Arg87, Arg10, Gly9, Gln7, Gln5, Thr5, Trp221, Phe222, Asn5, Pro223, Ser3, Ser226, Lys227 and Gly225 amino acid residues which inhibited the alpha-amylase more efficiently than acarbose (binding energy -4.71 $\mathrm{Kcal} / \mathrm{mol}$ ) (Figure 4). The docking results validated our in-vitro analysis of alpha-amylase inhibition.

Table 4. Binding energies of GC-MS identified compounds with the alpha-amylase enzyme.

\begin{tabular}{|c|c|c|}
\hline Compound name & $\begin{array}{l}\text { Binding } \\
\text { (Kcal/mol) }\end{array} \quad$ energy & Involved Residues \\
\hline $\begin{array}{l}\text { 4H-pyran-4-one, 2-hydroxy-3- } \\
\text { methyl }\end{array}$ & -3.64 & Asp402, Val401, Arg398, Gly403, Gly334, Pro332,Arg44 \\
\hline $\begin{array}{ll}\text { 9,12-octadecadienoic } & \text { acid } \\
(9 Z, 12 Z) \text {-methyl ester } & \end{array}$ & -3.88 & $\begin{array}{l}\text { Gly9, Arg10,Thr11, Gln8, Phe335, Gln7, Thr6, Pro6, } \\
\text { Arg92,Asn5, Ser3, Arg252,Tyr2, Gly251 }\end{array}$ \\
\hline Tetradecanoic acid (Myristic acid) & -4.18 & $\begin{array}{l}\text { Arg291, Arg252, Asp290, Tyr2, Ser3, Pro4, Lys227, Asn5, } \\
\text { Thr6, Arg10, Gly9, Gln8, Gln7 }\end{array}$ \\
\hline $\begin{array}{l}\text { Hexadecanoic acid } \\
\text { (Palmitic acid) }\end{array}$ & -3.81 & $\begin{array}{l}\text { Arg252, Tyr2, Ser3, Pro4, Lys227, Gly225, Ser226, Asn5, } \\
\text { Thr6, Gln7, Arg92, Gly90, Asn87, Trp271, Phe222, Pro223 }\end{array}$ \\
\hline 9-12,Octadecadienoic acid & -3.23 & $\begin{array}{l}\text { Phe222, Arg92, Pro223, Thr6, Ala224, Asn5, Ser226, } \\
\text { Gly225, Pro4, Pro228, Lys227, Phe229, Ser3, Ile230, Tyr2, } \\
\text { Arg252 }\end{array}$ \\
\hline $\begin{array}{l}\text { Phthalic acid, mono-(2- } \\
\text { ethylhexyl) ester }\end{array}$ & -4.33 & $\begin{array}{l}\text { Arg398, Val401, Asp402, Thr11, Gly9, Gly403, Phe375, } \\
\text { Gly334, Arg252, Ser289 }\end{array}$ \\
\hline stigmast-5-en-3-ol & -6.74 & $\begin{array}{l}\text { Gly90, Phe222, Pro223, Ser226, Lys227, Arg92, Gln7, } \\
\text { Thr6, Gln8, Gly9,Asn5, Pro4, Thr1, Arg398, Asp402, } \\
\text { Phe335, Gly334 }\end{array}$ \\
\hline Lupenyl acetate & -7.16 & $\begin{array}{l}\text { Val69, Asn88, Gly90, Asn87, Arg10, Gly9, Gln5, Thr5, } \\
\text { Trp221, Phe222, Asn5, Pro223, Ser3, Ser226, Lys227, } \\
\text { Gly226 }\end{array}$ \\
\hline
\end{tabular}

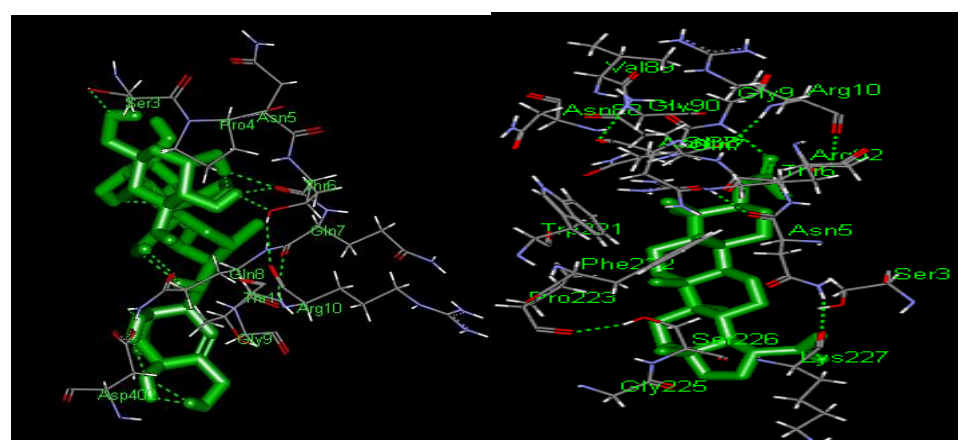

(a)

(b)

Figure 4. Binding patterns of Acarbose (a) and GC-MS identified compound Lupenyl acetate (b) With alphaamylase enzyme.

3.6. Discussion. 
The preliminary phytochemical screening was performed to authenticate the occurrence of biologically active plant metabolites in different solvent extracts, which confirmed the presence of total phenol and flavonoid contents. Many in-vitro studies have confirmed that anti-diabetic efficacy and other biologically useful medicinal plants' activities could be characterized by their high phenolic and flavonoid contents [24]. Based on their reducing properties, these secondary metabolites can neutralize free radicals, quenching singlet and triplet oxygen, or decompose peroxides to act as an antioxidant [11]. In the present study, the effects of different polarity solvents were analyzed for the percent yield of TPC and TFC in leaf extract of $P$. sylvestris. The TPC determined in different solvent extracts of $P$. sylvestris was expressed as $\mu \mathrm{g} / \mathrm{mg}$ of extract equivalent to Gallic acid and ranged from 10.75 to 31.55 $\mu \mathrm{g} / \mathrm{mg}$, whereas TFC ranged between 17.65 to $52.90 \mu \mathrm{g} / \mathrm{mg}$ of extract equivalent to quercetin. The compounds were extracted from plant samples by using polarity based solvents. However, the respective solvent's polarity plays a key role in extracting more specific bioactive compounds (phenols and flavonoids) for potential antioxidant activity [25-27].

About 300 million people have been suffering from a chronic metabolic disorder, diabetes mellitus. One of the curing strategies of diabetes is to minimize the absorption of glucose from the hydrolysis of carbohydrates by the inhibition of alpha-amylase enzymes [28]. A recent finding supposed alpha-amylase enzyme as a potentially targeted for the management of glucose level as well as diabetes mellitus and natural secondary metabolites (phenolics and flavonoids) were also reported for the inhibition activity of alpha-amylase [29-30]. Interestingly, ethyl acetate extract was identified as a potential alpha-amylase inhibitor among all the extracts. Maximum inhibition $(71.15 \%)$ was estimated in ethyl acetate extract at 500 $\mu \mathrm{g} / \mathrm{ml}$ concentration, comparable to acarbose (78.64\%). Although, previous reports of $P$. sylvestris have shown a significant presence of phytocompounds in other extracts with a satisfactory anti-diabetic approach in terms of hyperglycemic activity [31-32]. Ethyl acetate extract showed a concentration-dependent mixed type of alpha-amylase inhibition, whereas acarbose showed competitive enzyme inhibition, which is clearly demonstrated in fig. 2 . These observations strongly suggest that ethyl acetate extract constituents structurally resemble the substrate of the alpha-amylase enzyme, which interacts accordingly and inhibit the enzyme activity.

To identify the phyto-constituents of most potent ethyl acetate extract, the GC-MS examination was performed. Various major and minor components of hydrocarbons, ethers, phenols, terpinoids, flavonoids, alkaloids and steroids etc., were identified. Among all the present constituents, hexadecanoic acid (17.28\%), 4H-pyran-4-one, 2-hydroxy-3 methyl (10.02), 9, 12-octadecadienoic acid (9Z, 12Z)-methyl ester (8.32\%), tetradecanoic acid (8.18), lupenyl acetate $(8.05 \%)$ phthalic acid, mono-(2-ethylhexyl) ester (5.89\%), stigmast-5-en-3-ol (3.87\%), 9-12, octadecadienoic acid (2.11\%) was recognized which possess maximum percent area as found in the spectrum. Based on all activities, we can conclude that all major components are synergistically responsible for the activities because all identified components individually have a diverse type of medicinal and inhibitory properties, as earlier discussed by Duke [33]. Further, to validate the in-vitro alpha-amylase inhibition of all major components identified by GC-MS analysis were examined for in-silico analysis, which showed significant interactions in terms of binding energy and ligand efficiency. The observed binding energy of GC-MS components confirmed that ethyl acetate extract has much more potential to minimize the diabetic condition than the acarbose. Therefore, our results suggest that alpha-amylase inhibition of ethyl acetate extract might be due to GC-MS identified compounds' synergistic 
effect. Ethyl acetate extract needs to be further explored to isolate new and novel compounds for more potential anti-diabetic property which may prove to be more significant than synthetic drugs.

\section{Conclusions}

The present investigation concluded that $P$. sylvesteris leaf has several phyocompounds that will be incorporated with the anti-diabetic property. Based on in-vitro and in-silico studies, it was concluded that the lupenyl acetate compound present in the leaf extract has more affinity to inhibit the alpha-amylase enzyme activity and be considered for an effective role in counter the diabetes conditions. The present findings will be beneficial to the researchers to find out new directions in diabetes research.

\section{Funding}

This research received no external funding.

\section{Acknowledgments}

I would like to thanks Ms. Neeraj Sharma (LL.M) for their moral support to complete this work. I would also like to acknowledge Prof. Om Kumar Harsh, Hon`ble Vice-chancellor, and Mr. Nizamuddin, Registrar of Glocal University, Saharanpur, for providing a research environment. This research did not receive any specific grant from funding agencies in the public, commercial, or not-for-profit sectors.

\section{Conflicts of Interest}

The authors declare no conflict of interest.

\section{References}

1. Viña, J.; Borras, C.; Gomez-Cabrera, M.C. A free radical theory of frailty. Free Radical Biology and Medicine 2018, 124, 358-363, https://doi.org/10.1016/j.freeradbiomed.2018.06.028.

2. Koyuncu, I. Evaluation of anti-cancer, antioxidant activity and phenolic compounds of Artemisia absinthium L. Extract. Cellular and molecular biology (Noisy-le-Grand, France) 2018, 64, 25-34, https://doi.org/10.14715/cmb/2018.64.3.5.

3. Orathai, T.; Surapon, T. Oxidative Stress, Ocular Disease and Diabetes Retinopathy. Current Pharmaceutical Design 2018, 24, 4726-4741,https://doi.org/10.2174/1381612825666190115121531.

4. Tepe, B.; Eminagaoglu, O.; Akpulat, H.A.; Aydin, E. Antioxidant potentials and rosmarinic acid levels of the methanolic extracts of Salvia verticillata (L.) subsp. verticillata and S. verticillata (L.) subsp. amasiaca (Freyn \& Bornm.) Bornm. Food Chemistry 2007, 100, 985-989, https://doi.org/10.1016/j.foodchem.2005.10.062.

5. Bhattacharya, S.K. Hand book of medicinal plants. Pointer, Jaipur, 2001.

6. $\quad$ Seibert, J.B.; Viegas, J.S.R.; Almeida, T.C.; Amparo, T.R.; Rodrigues, I.V.; Lanza, J.S.; Frézard, F.J.G.; Soares, R.D.O.A.; Teixeira, L.F.M.; de Souza, G.H.B.; Vieira, P.M.A.; Barichello, J.M.; dos Santos, O.D.H. Nanostructured Systems Improve the Antimicrobial Potential of the Essential Oil from Cymbopogon densiflorus Leaves. Journal of Natural Products 2019, 82, 3208-3220, https://doi.org/10.1021/acs.jnatprod.8b00870.

7. Xia, B.H.; Xiong, S.H.; Tang, J.; Zhang, Z.M.; Li, Y.M.; Li, M.J.; Lin, L.M. [Extraction of flavonoids in Prunella vulgaris based on deep eutectic solvent method : application of new green solvent]. Zhongguo Zhong yao za zhi = Zhongguo zhongyao zazhi = China journal of Chinese materia medica 2018, 43, 34843492,https://doi.org/10.19540/j.cnki.cjcmm.20180702.002.

8. Alqadeeri, F.; Rukayadi, Y.; Abbas, F.; Shaari, K. Antibacterial and Antispore Activities of Isolated Compounds from Piper cubeba L. Molecules 2019, 24,https://doi.org/10.3390/molecules24173095.

9. (Platanus orientalis L.) leaf infusion against ethanol-induced oxidative stress in rats. Molecular Biology Reports 2019, 46, 3049-3061,https://doi.org/10.1007/s11033-019-04741-7. 
10. Ncube, B.; Finnie, J.F.; Van Staden, J. In vitro antimicrobial synergism within plant extract combinations from three South African medicinal bulbs. Journal of Ethnopharmacology 2012, 139, 81-89, https://doi.org/10.1016/j.jep.2011.10.025.

11. Wang, Y.; Qi, D.; Wang, S.; Cao, X.; Ye, Y.; Suo, Y. Comparison of Phenols Content and Antioxidant Activity of Fruits from Different Maturity Stages of Ribes stenocarpum Maxim. Molecules 2018, 23,https://doi.org/10.3390/molecules23123148.

12. Ritu, S.; Dinesh, C.S.; Mohammad, H.B.; Shabana, B.; Sudeep, R.; Ivo, P.; Mohammad, A.K. Antioxidant, Antimicrobial Activity and Medicinal Properties of Grewia asiatica L. Medicinal Chemistry 2016, 12, 211216, https://doi.org/10.2174/1573406411666151030110530.

13. Anwar, F.; Abbas, A.; Mehmood, T.; Gilani, A.-H.; Rehman, N.-u. Mentha: A genus rich in vital nutrapharmaceuticals_A review. Phytotherapy Research 2019, 33, 2548-2570, https://doi.org/10.1002/ptr.6423.

14. Derakhshan, Z.; Ferrante, M.; Tadi, M.; Ansari, F.; Heydari, A.; Hosseini, M.S.; Conti, G.O.; Sadrabad, E.K. Antioxidant activity and total phenolic content of ethanolic extract of pomegranate peels, juice and seeds. Food and Chemical Toxicology 2018, 114, 108-111,https://doi.org/10.1016/j.fct.2018.02.023.

15. Dransfield, J.; Uhl, N.; Lange, C.; Baker, W.; Harley, M.; Lewis, C. A new phylogenetic classification of the palm family, Arecaceae. Kew Bulletin 2005, 60, 559-569.

16. Couvreur, T.L.P.; Forest, F.; Baker, W.J. Origin and global diversification patterns of tropical rain forests: inferences from a complete genus-level phylogeny of palms. BMC Biology 2011, 9, https://doi.org/10.1186/1741-7007-9-44.

17. Corner, E.J.H. The natural history of palms.1966.

18. Santos, M.; Fortunato, R.H.; Spotorno, V.G. Analysis of flavonoid glycosides with potential medicinal properties on Bauhinia uruguayensis and Bauhinia forficata subspecies pruinosa. Natural Product Research 2019, 33, 2574-2578,https://doi.org/10.1080/14786419.2018.1460826.

19. Gu, D.; Fang, C.; Yang, J.; Li, M.; Liu, H.; Yang, Y. Chemical composition and $\alpha$-amylase inhibitory activity of the essential oil from Sabina chinensis cv. Kaizuca leaves. Natural Product Research 2018, 32, 711-713, https://doi.org/10.1080/14786419.2017.1332612.

20. Akanji, M.A.; Olukolu, S.O.; Kazeem, M.I. Leaf Extracts of Aerva lanataInhibit the Activities of Type 2 Diabetes-Related Enzymes and Possess Antioxidant Properties. Oxidative Medicine and Cellular Longevity 2018, 2018,https://doi.org/10.1155/2018/3439048.

21. Guan, B.; Zhang, C.; Zhao, Y. An Efficient ABC_DE_Based Hybrid Algorithm for Protein-Ligand Docking. International Journal of Molecular Sciences 2018, 19,https://doi.org/10.3390/ijms19041181.

22. Acharya, A.; Agarwal, R.; Baker, M.B.; Baudry, J.; Bhowmik, D.; Boehm, S.; Byler, K.G.; Chen, S.Y.; Coates, L.; Cooper, C.J.; Demerdash, O.; Daidone, I.; Eblen, J.D.; Ellingson, S.; Forli, S.; Glaser, J.; Gumbart, J.C.; Gunnels, J.; Hernandez, O.; Irle, S.; Kneller, D.W.; Kovalevsky, A.; Larkin, J.; Lawrence, T.J.; LeGrand, S.; Liu, S.H.; Mitchell, J.C.; Park, G.; Parks, J.M.; Pavlova, A.; Petridis, L.; Poole, D.; Pouchard, L.; Ramanathan, A.; Rogers, D.M.; Santos-Martins, D.; Scheinberg, A.; Sedova, A.; Shen, Y.; Smith, J.C.; Smith, M.D.; Soto, C.; Tsaris, A.; Thavappiragasam, M.; Tillack, A.F.; Vermaas, J.V.; Vuong, V.Q.; Yin, J.; Yoo, S.; Zahran, M.; Zanetti-Polzi, L. Supercomputer-Based Ensemble Docking Drug Discovery Pipeline with Application to Covid-19. Journal of Chemical Information and Modeling 2020, 60, 5832-5852,https://doi.org/10.1021/acs.jcim.0c01010.

23. Solis, F.J.; Wets, R.J.B. Minimization by Random Search Techniques. Mathematics of Operations Research 1981, 6, 19-30, https://doi.org/10.1287/moor.6.1.19.

24. Aourahoun, K.A.; Fazouane, F.; Benayache, S.; Bettache, Z.; Benayad, T.; Denni, N. Antioxidant and antiinflammatory activity of phenolic extracts of Genista ferox (Fabaceae). Pak J Pharm Sci 2019, 32, 26432649.

25. Bai, L.; Li, X.; He, L.; Zheng, Y.; Lu, H.; Li, J.; Zhong, L.; Tong, R.; Jiang, Z.; Shi, J.; Li, J. Antidiabetic Potential of Flavonoids from Traditional Chinese Medicine: A Review. The American Journal of Chinese Medicine 2019, 47, 933-957,https://doi.org/10.1142/S0192415X19500496.

26. Román, G.C.; Jackson, R.E.; Gadhia, R.; Román, A.N.; Reis, J. Mediterranean diet: The role of long-chain $\omega-3$ fatty acids in fish; polyphenols in fruits, vegetables, cereals, coffee, tea, cacao and wine; probiotics and vitamins in prevention of stroke, age-related cognitive decline, and Alzheimer disease. Revue Neurologique 2019, 175, 724-741,https://doi.org/10.1016/j.neurol.2019.08.005.

27. Zouhaier, B.; Asma, M.; Amina, M.; Fatma, H.; Hiroko, I.; Sami, S. Contribution of Major Polyphenols to the Antioxidant Profile and Cytotoxic Activity of Olive Leaves. Anti-Cancer Agents in Medicinal Chemistry 2019, 19, 1651-1657,https://doi.org/10.2174/1871520619666190416101622.

28. Melo da Cunha, J.d.S.; Alfredo, T.M.; dos Santos, J.M.; Alves Junior, V.V.; Rabelo, L.A.; Lima, E.S.; Boleti, A.P.d.A.; Carollo, C.A.; dos Santos, E.L.; de Picoli Souza, K. Antioxidant, antihyperglycemic, and antidiabetic activity of Apis mellifera bee tea. PLOS ONE 2018, 13, https://doi.org/10.1371/journal.pone.0197071.

29. Zhang, L.-L.; Han, L.; Yang, S.-Y.; Meng, X.-M.; Ma, W.-F.; Wang, M. The mechanism of interactions between flavan-3-ols against a-glucosidase and their in vivo antihyperglycemic effects. Bioorganic Chemistry 2019, 85, 364-372,https://doi.org/10.1016/j.bioorg.2018.12.037. 
30. Xiao, J.; Kai, G.; Ni, X.; Yang, F.; Chen, X. Interaction of natural polyphenols with $\alpha$-amylase in vitro: molecular property-affinity relationship aspect. Molecular BioSystems 2011, 7, 1883-1890, https://doi.org/10.1039/c1mb05008g.

31. Zeng, P.; Li, J.; Chen, Y.; Zhang, L. The structures and biological functions of polysaccharides from traditional Chinese herbs. Prog Mol Biol Transl Sci.2019, 163,423444,https://doi.org/10.1016/bs.pmbts.2019.03.003.

32. Sharma, D.C.; Shukla, R.; Ali, J.; Sharma, S.; Bajpai, P.; Pathak, N. Phytochemical evaluation, antioxidant assay, antibacterial activity and determination of cell viability (J774 and THP1 alpha cell lines) of P. sylvestris leaf crude and methanol purified fractions. EXCLI journal 2016, 15, 85-94, https://doi.org/10.17179/excli2015-689.

33. Duke, J.A. Handbook of Biologically Active Phytochemicals and Their Activities. CRC Press, 1992. 